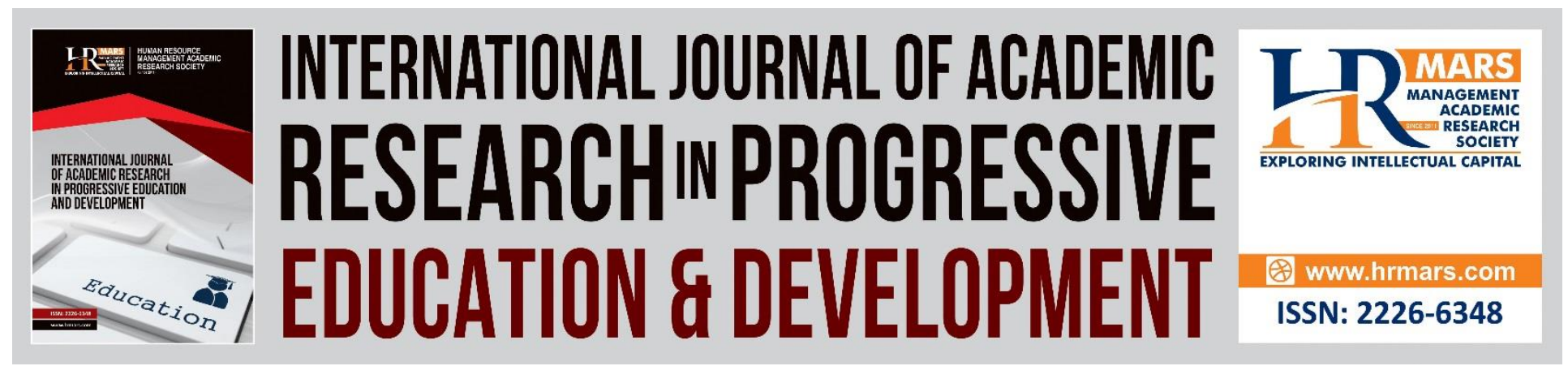

\title{
Forms of and Suitability of the Techniques used for Delegation by Primary School Head Teachers in Kenya: A Case of Kosirai Division of Nandi County
}

Kipkoech Lydia Cheruto, William Kutto, Koross Rachel Chepchumba

To Link this Article: http://dx.doi.org/10.6007/IJARPED/v7-i1/3858 DOI: 10.6007/IJARPED/v7-i1/3858

Received: 12 Dec 2017, Revised: 25 Jan 2018, Accepted: 20 Feb 2018

Published Online: 08 Mar 2018

In-Text Citation: (Cheruto, Kutto, \& Chepchumba, 2018)

To Cite this Article: Cheruto, K. L., Kutto, W., \& Chepchumba, K. R. (2018). Forms of and Suitability of the Techniques used for Delegation by Primary School Head Teachers in Kenya: A Case of Kosirai Division of Nandi County. International Journal of Academic Research in Progressive Education and Development, 7(1), 38-46.

Copyright: (C) 2018 The Author(s)

Published by Human Resource Management Academic Research Society (www.hrmars.com)

This article is published under the Creative Commons Attribution (CC BY 4.0) license. Anyone may reproduce, distribute, translate and create derivative works of this article (for both commercial and non-commercial purposes), subject to full attribution to the original publication and authors. The full terms of this license may be seen at: http://creativecommons.org/licences/by/4.0/legalcode

Vol. 7, No.1, January 2018, Pg. 38 - 46

Full Terms \& Conditions of access and use can be found at http://hrmars.com/index.php/pages/detail/publication-ethics 


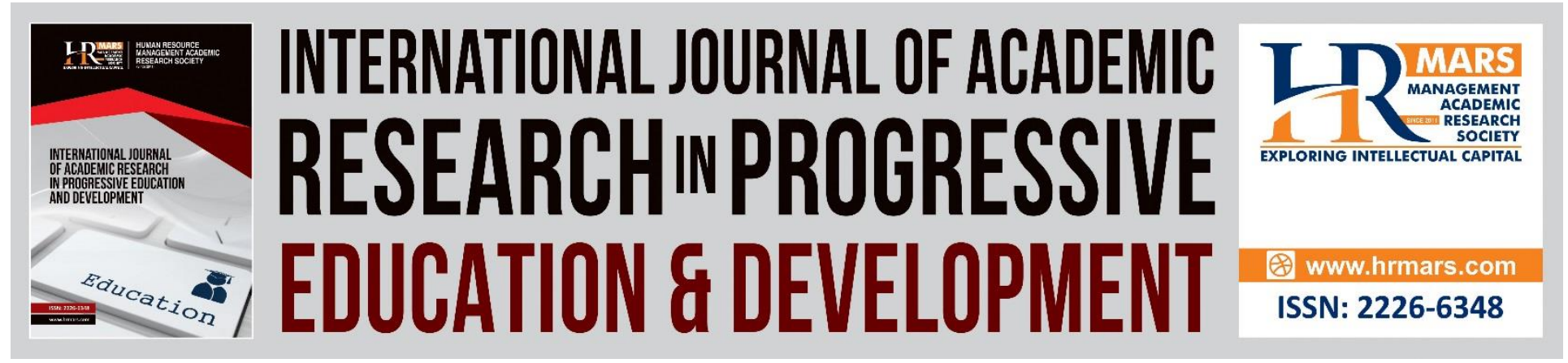

\title{
Forms of and Suitability of the Techniques used for Delegation by Primary School Head Teachers in Kenya: A Case of Kosirai Division of Nandi County
}

\author{
Kipkoech Lydia Cheruto \\ University of Eldoret \\ Email:cherulk@yahoo.com \\ William Kutto \\ Administrator, Moi University \\ Koross Rachel Chepchumba \\ University of Eldoret
}

\begin{abstract}
This study investigated the effects of delegation on managerial effectiveness in Kosirai Division of Nandi County. The objectives of the study were to identify forms of delegation used by primary school head teachers and to determine the suitability of the techniques used for delegation by primary school administrators. The study was based on human resource model of management theory advanced by Miles (1975). The methodology was a descriptive survey where questionnaire and interview schedules were tool of data collection. The target population was a total of 289 head teachers and teachers from Kosirai Division of Nandi County who were selected using both purposive and stratified sampling techniques. Data was analysed using descriptive statistics where finding were presented in the form of frequencies and percentages. The study established that teachers have positive attitude towards delegation and that most of them were keen on accomplishing tasks assigned to them by their Head teachers for example meeting their deadlines. Therefore, there is need for the School Managers to encourage teachers by giving rewards for good performance, and use appropriate Written/formal form of delegation.

Keywords: Delegation, Education, Forms, Management, Suitability, Teachers

Introduction

Delegation is a process by which managers such as school heads transfer part of their authority to subordinates, for the performance of certain tasks and responsibilities. Delegation produces
\end{abstract}




\section{INTERNATIONAL JOURNAL OF ACADEMIC RESEARCH IN PROGRESSIVE EDUCATION AND}

\section{DEVELOPMENT}

Vol. 7, No.1, January 2018, E-ISSN: 2226-6348 @ 2018 HRMARS

better managers and a higher degree of efficiency. This collective effort, resulting in organization growth, is dependent on delegation of authority (Olembo \& Cameron, 1986).

According to Daft (1999) most organizations encouraged managers to delegate authority to all possible levels to provide maximum flexibility in order to satisfy customer needs and adapt to the changing environment. According to Taylor's scientific theory, division of roles and responsibilities is important to enable workers to perform efficiently in the highest grade of work for which he has natural abilities to fit besides and getting higher wages in return. This means mental revolution in the employee and change of attitudes towards organization. Taylor was convinced, that with better efficiency in methods of work and management control, there would be an increase in output and surplus for the benefit of the producing worker.

Globally, the school administrative structure was hierarchical in most cases with the head teacher at the top and teachers and prefects at the bottom. However, Bennis, Spreitzer, Grettchen, and Cummings (2001) pointed out that hierarchical organizations were simply too inflexible and rigid to compete effectively in today's environment. These sometimes affected the process of delegation of duties and responsibilities.

In an evaluation of school improvement process in New Brunswick, Hargreaves (2003) established that there were serious concern in school leadership, teaching and learning. In an attempt to address these concerns in school leadership, characterized by increasing complexity of school head teachers in New Brunswick, he encouraged school head teachers to embrace the concept of distributed leadership, shared systems of responsibility, and promotion of continuous professional development of teachers.

The National Committee on Educational objectives and policies otherwise known as Gachathi Report (1976) on the other hand, while addressing the subject of "management of education and training" endorsed that secondary be run by Boards of Governors and primary schools be run by School Management Committees, and recommended a higher degree of delegation in order to enhance effective management of schools.

The management of public secondary schools in Kenya is vested with BOGs appointed by the Minister of Education in accordance with Section 10 of Education Act Cap 211 (1980). District Education Boards (DEB) also has authority to mange schools in their respective Districts. The Teachers Service Commission(TSC) code of regulations (1986) gives powers to Provincial Directors of Education(PDE),District Education Officer (DEO) and the Board of Governors (BOG) to manage teachers as TSC agents (TSC code of regulations 1986). The delegation of managerial duties to PDE, DEO and BOG stemmed from the realization that centralization of functions within the ministry of Education was leading to inefficiency and unnecessary bureaucratic delays in the execution of duties by the education officers in the field.

Recent reports also indicate that most teachers and deputy head teachers were still lacking management skills in school leadership. Of late, there have been complaints about poor school management in many primary schools, with parents, politicians and students and sometimes Ministry of Education officials, blaming the head teachers of high handedness and poor K.C.P.E. examinations results. In some instances, these complaints have led to parents closing schools, 


\section{INTERNATIONAL JOURNAL OF ACADEMIC RESEARCH IN PROGRESSIVE EDUCATION AND}

DEVELOPMENT

Vol. 7, No.1, January 2018, E-ISSN: 2226-6348 @ 2018 HRMARS

transfer of head teachers, or demotion of some head teachers. This was a reflection that some head teachers were not adequately sharing some of their duties and responsibilities with teachers through delegation.

At the school, the head teacher is placed in a position of responsibility and authority where all major decisions; curriculum and instruction, management of student discipline, school organization and staff personnel matters, financial matters, school and community relations among others are centered on his /her office (Ministry of Education, 1975). To assist the head teacher in decision making and policy formulation and implementation is the Board of Governors, which deliberates on important decisions like hiring of support staff and budgeting for the school (Education Act. Cap. 211).

The hierarchical structure that places head teachers at the apex of a pyramid of staff is a common feature in both primary and secondary schools in Kenya. In this arrangement school heads are poised to use their superior knowledge and experience to direct and control the working of the entire school. This negatively affects efficiency and productivity of the schools because teachers work at half steam because they are not effectively involved in decision making to make them feel as part of school. Owing to the dynamics of professionalism and diversity of ideas in schools occasioned by staffing schools with professionally trained teachers and the need to decentralize decision making to the lower levels, the hierarchical structure in management of schools is challenged. On many occasions, head teachers have been advised to involve teachers in decision making as a way of motivating them and to create a feeling of belonging.

It was apparent that school administrators should put in place some mechanisms that would lead to effective delegation process of duties and responsibilities in schools they should put in place appropriate measures to improve it and to enable the school achieve its objectives.

In a bid to achieve the educational goals, school managers are expected to run schools effectively. To run a school effectively, the head teacher is central in setting the tone of the school. In light of pressures of responsibilities on the part of the head teacher, it was paramount that some of these responsibilities were effectively delegated to other members of staff in the school. The head teacher employs management styles, which ensures effective learning by children and teaching by teachers. Many head teachers are faced with administrative challenges as they discharged their duties and responsibilities such as inadequate staffing, and improvement of learning and teaching facilities.

Although delegation of responsibility is important, many schools in Kenya were still characterized by poor delegation practices. Griffin, (1994) suggest that any school head that wants to succeed must avoid falling victim to the sheep syndrome in which teachers are seen as a faceless herd to be led, directed and instructed without any creativity and knowledge. Wanjiku (1985) has complained that head teachers do not involve teachers in running of their schools. He asserted that some head teachers absent themselves from school without informing anybody, resulting in delayed decisions and sometimes leading to lessons not being taught. These could be attributed to the reasons why delegation of duties and responsibilities in primary schools in Kosirai Divison 
DEVELOPMENT

Vol. 7, No.1, January 2018, E-ISSN: 2226-6348 @ 2018 HRMARS

needed to be investigated. This raised question concerning how head teachers delegate duties and responsibilities, and who handled their responsibilities when they were away.

In an educational assessment report for primary schools in Nandi North District, Kosirai Division a team of 5 quality assurance officers and auditors drawn from other districts in Rift Valley Province carried out an assessment in 7 public schools in Kosirai Division. The report revealed that delegated duties were poorly supervised in most schools, leading to poor performance of duties and responsibilities and non-achievement of set goals and targets. These findings confirmed that there were inadequacies in the delegation of duties and responsibilities among head teachers in public primary schools in Kosirai Division. This was in agreement with Aduda, (1988), and MoE (2002) that gave a report that there was lack of proper delegation of duties and responsibilities in many schools. Questions now come; what could be the reasons why performance of duties and responsibilities are done poorly in Kosirai Division?

\section{Research Objectives}

The study sought to achieve the following objectives:-

i. To identify forms of delegation used by primary school head teachers in Kosirai Division of Nandi North District.

ii. To determine the suitability of the techniques used in delegating duties and responsibilities by primary school Head Teachers in Kosirai Division, Nandi North District.

\section{Theoretical Framework}

This study was based on human relations and human resources models of management participative management, or the amount of consultation the head teacher has with subordinates, is a central theme in both of these models of managing. Miles states that in the Human Relations model, participation in the decision-making process stresses the amount of subordinate involvement. The model implies that participation in routine organizational matters or limited consultation on important issues is sufficient to produce the desired result; that is, the subordinates will be cooperative, enthusiastic, and satisfied.

This model was derived from the dual-model theory advanced by Miles (1975). In this study, the human relations and human resource model of Miles (1975) gives guidance to the head-teachers to focus on sharing of ideas with teachers in decision making. The model calls for obtaining the organizational matters that leads to positive contributions in achieving organizational goals and urge managers to allow subordinate to participate fully in the organizational matters because these are expectations of the subordinates. The human relations model is modified and gives attention to social and egoistic needs. It recognizes the fact that fair treatment and pay are enough.

Managers here, emphasize controlling although preventive steps are also taken to obtain the desired contribution of institutional members. The human relations model accepts the fact that people share a commonest of needs: to belong, to be liked and to be respected while the human resource model professes that people not only share the needs to belong and be respected, but they also desire to contribute effectively and creatively to the accomplishment of worthwhile organizational objectives. Delegation in primary schools is very important as it plays a crucial role 
DEVELOPMENT

Vol. 7, No.1, January 2018, E-ISSN: 2226-6348 ๑ 2018 HRMARS

in ensuring accountability, improvement in performance, reduce wastage of resources hence justify continued Government financial support to education.

For the school administration to succeed in its' endeavours, there is need for the head teachers to involve the staff members in their institutions in decision making during staff meetings. This will give chance to every teacher to contribute positively to the success of their schools. Since human beings are the most important part of their institutions, everything possible must be done by the head teachers to make them comfortable in their work. An institution which considers the comfort and the social welfare of its workers can be said to be employee - centered. Increased productivity on the part of the teachers occurs when their basic human needs are given due consideration by the head teacher, this is because human beings work well when they are happy within their working environment (Mbiti, 2007). Hence this has helped the researcher to come up with the research problem that is aimed at achieving the research objectives in order to address problems that arise out of luck of delegation of responsibility in primary schools in Kosirai Division.

\section{Methodology / Research Design}

The study adopted the descriptive survey design. The survey research design was deemed appropriate because the researcher intended to use questionnaires and interviews to get information from the participants. Cozby, (2001) asserted that survey research employed questionnaires and interviews to get information about people's attitudes, beliefs, demographics, perceptions, and past or intended future behaviours. Descriptive survey is a method of collecting information by interviewing or administering a questionnaire to a sample of individuals (Orodho, 2003).

This study was carried out in Kosirai Division, Nandi North District. The Division has two zones namely; Mutwot zone and Lelmokwo zone and its headquarters is Mosoriot urban centre. The area was chosen because there had been reported cases of teachers refusing to take up positions as head teachers and some head teachers stepping down from leadership positions (Head teacher's meeting in Kosirai Division Lelmokwo Zone 2008). The target population for this study was primary schools, head teachers and teachers. The sample size of the study consisted of 18 head teachers and 98 teachers drawn from the target population giving a total of 116 (40\%) teachers. The main research instruments for data collection were questionnaires and interview schedules. Data collected was analysed descriptively and findings were presented in Tables, frequencies and percentages.

\section{Results}

\section{Forms of delegation used by primary school head teachers.}

The study sought to find out which form of delegation the Head teachers used in assigning duties to the teaching staff and determined their level of commitment a head teacher has during assignment of delegation. The study established that majority 12 (66.67) head teachers indicated that they used Written/formal form of delegation, while 6 (33.33\%) head teachers indicated that they used verbal/informal form of delegation.

On the issue of consulting before delegating duties and responsibilities, the study established that majority 17 (94.44\%) head teachers were in agreement that they always do thorough 


\section{INTERNATIONAL JOURNAL OF ACADEMIC RESEARCH IN PROGRESSIVE EDUCATION AND}

\section{DEVELOPMENT}

Vol. 7, No.1, January 2018, E-ISSN: 2226-6348 @ 2018 HRMARS

consultation during decision making while $1(1.12 \%)$ was undecided. This was important in assess teamwork and unity of purpose in schools. This was in agreement with (Olembo \& Cameron1986) who stated that the head teacher should consult his/her teachers about what he or she proposes to give them to do.

The study consequently, established that some head teachers used upward form of delegation in assigning duties and responsibilities, this was important to determine the effectiveness of delegation. The respondents who indicated that they used upward form of delegation were 14 (77.78\%) head teachers while 4 (22.22\%) head teachers disagreed.

From the open ended questions it was found out that all $5(100 \%)$ head teachers who were interviewed indicated that they were in school most of the time and that all $5(100 \%)$ head teachers indicated that they kept record of duties assigned to the teachers, delegated duties and responsibilities regularly and agreed that delegation in school promotes management of schools.

\section{Suitability of the techniques used in delegating duties and responsibilities.}

The study sought to find out the benefits of a suitable technique as viewed by the teachers, this was important to establish the decision making process in the school. The response was that majority of the teachers $92(93.88 \%)$ accepted that a suitable technique used in a school promotes friendliness and support among teachers and head teachers while $6(6.12 \%)$ teachers were of contrary opinion. Moreover, the study revealed that majority 51 (52.04\%) teachers indicated that delegation of duties and responsibilities promoted teamwork among teachers. The study further revealed that, $40(40.82 \%)$ teachers indicated that a suitable method of delegation encourage innovation and creativity among teachers. Furthermore, 5 (100\%) of the head teachers indicated that the use of delegation as a tool of management empowers teachers to make informed decisions on their own that will assist the head teachers in management of their schools. This was in agreement with Paisey, (1998) who said that delegation empowered teachers to make decisions at any level they were involved and should therefore be given the full responsibility to complete a task or project, that delegation was necessary in order to utilize skills and talents that some members of staff already have, which may be superior to those of the head teachers.

All head teachers delegated duties and responsibilities after consulting with the teachers. Head teachers spent most of their time in school this indicated that delegation was monitored very closely or the head teachers did not trust their teachers in handling delegated duties. Majority of the teachers indicated that the head teachers selected the right persons for the right task, and identified the task to delegate, they also consulted and delegated duties to their teachers and gave authority to their teachers to perform delegated duties. It was also established that only $50 \%$ were given incentives for good work done, moreover, head teachers encouraged innovative and creative skills among teachers. It was established that $94 \%$ of the teachers indicated that there was extensive interaction and collaboration in the school, where the head teacher informed them about new goals. Teachers indicated that, delegation promoted teamwork and techniques used were suitable. Head teachers periodically evaluate progress of delegated duties. Teachers had a positive perception about delegation.

The findings revealed that majority 17 (94.44\%) head teachers in Kosirai Division indicated that they were faced with a lot of challenges from their teachers who were not willing to cooperate 
DEVELOPMENT

Vol. 7, No.1, January 2018, E-ISSN: 2226-6348 @ 2018 HRMARS

to assist the head teacher perform his/her administrative functions while 1 (56\%) disagreed. These problems would help in making suggestions on how to carry out seminars or guiding and counseling programs for primary school teachers in Kosirai Division.

\section{Conclusion}

The broad objective of the study was to investigate the effects of delegation on managerial effectiveness in Kosirai Division of Nandi County. The study concludes that most primary schools Kosirai Division of Nandi County had some short comings that hindered effective delegation of responsibilities. Secondly, majority of the head teachers did not properly delegate responsibilities to their staff.

The study also established that the actual extent of teacher participation in decision-making was less than the desired extent of teacher participation in decision-making it was therefore, concluded that teachers yearn for more involvement in decision-making than they were actually involved. Also, the strategies used by school head teachers while delegating duties and responsibilities were not adequate. The findings further revealed that a few other head teachers followed particular steps while delegating, such as identifying the task, selecting the person, and monitoring the delegated tasks.

It was also established that delegation improved managerial effectiveness and the success depended on the head teacher's skills, encouragement of innovative, creative, friendly advice and support, information on new goals and authority to perform delegated duties. Suitable form of delegation which was also a challenge in a number of schools included identifying tasks to be delegated, majority of the head teachers did consultation, promoted extensive interaction and collaborated with their teachers on tasks to be delegated, they also did the selection of the right person for the best task, moreover they gave authority to their teachers over delegated duties.

\section{Recommendations}

Based on the findings and conclusions this study recommends the following;

1. Primary school head teachers should improve the scope of responsibilities delegated to teachers. Teachers should be given authority to make decisions on delegated duties. Head teachers should take into account the qualities of teachers while delegating responsibilities.

2. Proper steps should be taken by Ministry of Education in ensuring that training of teachers in various colleges should emphasize on management skills. Training should foster on the importance of participatory decision- making, collective responsibility and sharing of ideas among teachers and school heads. Government should ensure that qualified teachers are promoted to take up leadership positions in primary schools in Kenya.

3. Head teachers should provide adequate guidance to the teachers in order to enable teachers perform delegated duties successfully Newly appointed teachers as well as experienced teachers who needed to be given delegated tasks should be encouraged by head teachers by giving them guidance and direction. 
INTERNATIONAL JOURNAL OF ACADEMIC RESEARCH IN PROGRESSIVE EDUCATION AND

DEVELOPMENT

Vol. 7, No.1, January 2018, E-ISSN: $2226-6348$ c 2018 HRMARS

CORRESPONDING AUTHOR: KIPKOECH LYDIA CHERUTO Email.cherulk@yahoo.com

\section{REFERENCES}

Adhola, D. (1985). Kenya News Agency. Daily Nation. Nairobi: Nation Media Group

Cozby, P.C. (2001). Methods in Behavioral Research (7th Ed.). California: Mayfield Publishing Company.

Daft, R.L. and Marcic, D. (2006). Understanding Management. U.S.A: Thomson South Western.

Gachathi, P. (1976). Report of the National Committee in Educational Objectives and Policies. Republic of Kenya.

Griffin, G. (1994). School mastery: Straight Talk about boarding school management in Kenya. Nairobi: Lectern Publishers Ltd.

Mbiti, D. (2007).Foundation of school administration. New York: Oxford University Press East Africa Ltd.

Miles, R. (1975). Theories of management: Implications for organizational behaviour and development. New York. McGraw Book Co.

Ministry of Education (1975).A manual for Head teachers. Nairobi: Government printers.

Ministry of Education Science and Technology (2003). Schools Management Handbook Nairobi. Jomo Kenyatta Foundation

Olembo, J.O. and Cameron, J. (1986). Practical Primary School Administration for Students, Teachers and Heads. Edward Arnold Publishers: Waverley Road.

Orodho, A.J. (2003). Essentials of Educational and Social Sciences Research Methods: Masola Publishers, Nairobi.

Paisey, A. (1998).Effective Management in Primary Schools. England: Basil Blackwell Ltd.

Teachers Service Commission Code of Regulation (1986).Nairobi: Government Printer

Teachers Service Commission(2002). Operational manual on teacher management. Nairobi: Jomo Kenyatta Foundation.

Wanjiku, E. (1985). Why Head teachers Fail: Education Supplement Vol. 2 